\title{
An Application of the Marketing Mix and Online Marketing as a Business Strategy for SMME Cafés in
} South Africa

\author{
*Meenakshi Gujral, Monwabisi Rauzela, Tinashe Chuchu \\ University of the Witwatersrand, South Africa \\ Meenakshi.Gujral@wits.ac.za
}

\begin{abstract}
The objective of the study was to examine the impact of marketing mix and online marketing on SMME cafés in South Africa as a marketing strategy. The study was an exploratory research design which sought to get new insights into the activities of how marketing strategies could be adopted into the SMME's in South Africa. Convenience sampling technique was used in selecting 5 small to medium cafés from Braamfontein, located in the Centre of Johannesburg, South Africa. Data was collected from both primary and secondary sources. Primary data was in form of focused group discussions and interviews to elicit information for the study, while the secondary data was culled from other related works, libraries as well as information from the internet. Qualitative research approach was adopted in analysis of the data. The study has proven that café owners or brand strategists do implement an integrated marketing strategy embracing both marketing mix and online marketing. The study also revealed that, online marketing was an effective platform to help communicate a desired message to the target audience. The study recommended for marketers to recognize the importance of embracing and employing an integrated marketing strategy. There is also the need for café owners to be effective in using integrated marketing strategy.
\end{abstract}

Keywords: Small, Micro and Medium Enterprises (SMMEs), marketing mix, marketing strategy, online marketing

\section{Introduction}

The use of internet-based tools to support businesses has received much attention from both researchers and practitioners (Cagliano, Caniato \& Spina, 2003). However, despite the initial excitement generated by expectations from online based tools, it is still not completely clear whether these expectations have been translated into business reality (Cagliano et al., 2003). More recently according to Erdoğmuş and Cicek (2012) marketers have utilised social media marketing to maintain the brand loyalty of their customers. Lamb, Hair, McDaniel, Boshoff, Terblanche, Elliot and Klopper (2010) suggest that most marketing strategies usually comprise of aspects such as public relations and publicity, personal selling and sales promotion to reach the desired target market and meet its needs and wants simultaneously as well as realising the firm's objectives. The combination of all these aspects is known as the marketing communication mix (Lamb et al., 2010). The present research seeks to establish whether the marketing mix and online marketing are a feasible thereof a viable business strategy for cafés in the SMME industry.

Since the Internet has provided start-ups and small businesses with an effective low-cost means to reach consumers, it has become imperative to the strategic approach of these businesses (Llorens, 2014). Small, Micro and Medium Enterprises (SMME) have been lauded by both the government of South Africa and commerce experts as a viable solution to overcoming major socio-economic issues that include; the high unemployment rate, low income levels and the persistent poverty that continues to hold South Africa back from economic prosperity (Edwards \& Schoer, 2001).The government has showed commitment towards facilitating the formation, growth and the development of small businesses. However, the attainment of a high success rate of small businesses is yet to become a reality, as indicated by the staggering $75 \%$ percent failure rate of small businesses within South Africa (Olawale \& Garwe, 2010). This high failure rate can be attributed to a wide variety of obstacles which pertain to both external and internal factors. External factors pertain to exogenous macro-economic variables that are beyond the scope of any SMME. Internal factors include, lack of skilled labour, unsound business plan, lack of funding and expertise in key functional areas, which include finance, human resource and marketing. 
Common mistakes made by SMME's include not having a marketing plan, a flawed pricing strategy, having a mismatched market segment and putting emphasis on marketing aspects that should be considered at a later stage of the business (Murphy, 2001; Caprino, 2013).The present research aims to determine whether SMME's within the café industry implement an integrated marketing strategy that includes the marketing mix and online marketing; in order to achieve pre-specified marketing and financial objectives, thus decreasing their chances of failing. Previous literature has been written on the subject matter; however most is not applicable to South Africa and lacks sight of aligning a marketing strategy with the organisational goals, vision and objectives. Linking a marketing strategy with the vision, goals and organisational objectives is of paramount importance, because marketing is one of the key tools that are used within an organisation to acquire a competitive advantage and create sustainable shareholder value.

Key objectives of the study are as follows: The present study seeks to establish whether the marketing mix can be adopted as a viable business strategy for SMMEs in the café industry. Also, if there is an alignment between cafés marketing strategies with their organisational vision, goals, marketing and financial objectives. The study further seeks to find out whether online marketing can be utilised as a business strategy for SMMEs in the café industry. And lastly, to recommend an effective integrated marketing strategy that embraces both, the marketing mix and online marketing techniques, in order to aid cafés, achieve success. The first section of the present paper explored the introduction. The following sections will discuss the literature review, research methodology, discussion of results, conceptual framework, implications of the study and finally the conclusions.

\section{Literature Review}

The review of literature plays a crucial role in the current research. In this section efforts are directed to explore or assess the findings of the studies conducted by various scholars in the same field. Below is the empirical review of literature for the study.

Overview of SMME's in South Africa: Small to medium businesses in South Africa fall under a sector called Small, Micro and Medium Enterprises (SMME). Literature defines small business in different ways, however a formal definition used widely in South Africa is in the National Small Business Act of 1996, which is "a separate and distinct business entity, including co-operative initiatives and non-governmental organisations, managed by one owner or more which, including its subdivisions or subsidiaries, if any, is principally conducted on in any sector or subsector of the economy" (National Small Business Act, 1996). Strong evidence definitely attests to this, as indicated by the high $52 \%$ to $57 \%$ contribution to the national GDP and approximately 61\% to employment (Small Enterprise Development Agency, 2013).Furthermore, it is believed that the SMME sector can still play a far more significant role in driving our economy forward if explored to its full potential (Agupusi, 2007).

Café industry in South Africa: In South Africa, the entire industry is worth R3.2 Billion as reported last year November (De Waal \& Pienaar, 2013). In 2013 the country saw the first and the only township café called the Department of Coffee which is based in Khayelitsha flourish, and that can be ascribed to the national surge in coffee culture. "South Africans enjoy meeting up in cafés and bars on social occasions with friends and family and the increase in disposable incomes has boosted the demand in this sector" (Consumer Foodservice, 2005, p: 28). The number of successful cafés all around the country has been and continues to increase exponentially.

Marketing strategy: According to the strategic management discipline, a strategy is directed by the organisations broader vision and objectives aimed at long term achieving success (Louw \& Venter, 2012). The definition and the function of marketing and its strategic bearing vary within literature. Jain (2000) proposed that a marketing strategy can be looked at as a triangular model that consists of three complementary c's which are: customer, corporation and competition. Through a marketing strategy a corporation can outwit competition and better satisfy the needs of its consumers. Marketing strategy refers to an organisation's integrated approach to decisions that specify its crucial choices concerning products, markets, marketing actions and marketing resources in the creation, communication and/or delivery of products that offer value to customers in exchanges with the organisation and thereby allowing the organisation to accomplishments 
specific objectives (Varadarajan, 2010). The above definition and concept is in line with that stance of the research that a marketing strategy should be informed by the organisations broader vision, in order to achieve various objectives such as generating profit, driving revenue, accelerating market share, in order to create a sustainable value over a long period.

Integrated marketing strategy: The various marketing strategies are: marketing mix, product life cycle, market share and competition. Out of the four aforementioned issues, the research will only consider marketing mix as a primary base for an effective marketing strategy (Lee, Ko, Tikkanen, Phan, Aiello, Donvito \& Raithel, 2014). Greenley (1984) defines marketing strategy as being an indication of how each element of the marketing mix will be used to achieve the marketing objectives. This definition gives complete reliance on the marketing mix. However, it is believed that a marketing mix is a simplified and restricted approach to a marketing strategy. Therefore, the stance of the research seeks to look at the subject matter from an integrated perspective, hence the inclusion of online marketing. As of late, many entrepreneurs are to their detriment, are edging out crucial traditional marketing concepts and communication mediums. Caprino (2013) noticed that many are focused on growing an online following, before developing an innovative product or service with a sustainable competitive advantage and a complementary revenue management system. The adoption of this school of thought and practise has been aided by expert's support of new innovative marketing over traditional marketing. Levinson (2007) founder and champion of guerrilla marketing went on an in depth discussion on how effective guerrilla marketing is over traditional marketing. He brands it as a number one marketing success enabler for entrepreneurs. However, on the other hand, Williams (2006) noted that small businesses particularly within the tourism and hospitality sector (which includes cafés), are reluctant to let go of traditional methods as they have not embraced new innovative trendy and effective marketing mediums. Therefore, the stance of this research is that small businesses, particularly cafés must implement an integrated marketing strategy, which takes into account the 4 ps of the marketing mix and online marketing.

Marketing mix: Borden (1964) formulated an analogy, that a marketing mix is a recipe that consists of a mixture of ingredients created by a mixer to create a valuable end product, that is, a "profitable business operation". The marketing mix has been widely adopted by both large and small firms, because it is an easily remember able framework within which marketing decisions can be made and implemented. The four marketing mix is: the product, price, place and promotion. Kotler (2006) defined price as an "amount of money charged for a product or a service or the sum of all values that customers give up in order to gain the benefit of having or using a product or service. Therefore, when setting price points, marketers need to consider the consumer's subjective point of view. According to Yoo, Donthu and Lee (2000), "perceived marketing efforts play a more direct role in consumer psychology than actual marketing efforts". This implies that what consumers perceive to be true has the power to drive change in the consumer behaviour and consumption pattern. Place is a platform in which a consumer can get access to a desired product or service (Yeu, Leong, Tong, Hang, Tang, Bashawir \& Subhan, 2012). It is twofold; it primarily consists of channel management and logistics management (Czinkota \& Ronkainen, 2012). Channel management deals with the entire process of setting up and managing distribution channel, storage facility, location, warehousing, and transportation and so on. Logistics management focuses on providing a needed product or service at the right time and place through an appropriate channel (Czinkota \& Ronkainen, 2012). A well thought out name tends to signals quality or what the brand stands for (Yoo et al., 2000). In essence, marketers need to be cognisant of the fact that an appealing store attracts consumers and increase consumer's satisfaction levels. Marketers use promotion to shape consumers perception about their products or the brand, through conveying a desirable image that reflect what the brand stands for (Fransiska, Andhika, Indra \& Rengganis, 2012).

Online marketing: The advent and advancement of technology has led to the inception and success of online marketing. Gurau (2008) proposes that in order to create an effective message, marketers need to use a three stage framework. Firstly, the message should incorporate the DNA of the brand, the overall corporate values and principles. Secondly, the message must be aligned with fundamental objectives and lastly, the message needs to be adapted to the target audience and the channel of choice. Over the years, online marketing has gained attention and importance due to traditional advertising losing momentum, consumers increase in disposal income, lack of free time and so on. Nowadays consumers are fast becoming technologically and money savvy, they want instant access to relevant information, before committing to a purchase decision. 
According to Gurau (2008), the internet provides consumers with numerous platforms to discuss anything about a firm on the open. Online marketing is still in its growing phase, it poses endless opportunities that have not been fully exploited by many businesses, especially SMME's.

\section{Methodology}

The following methods were used for the present research.

Sample and Data collection: A sample is selected from a population, which is a complete group of elements who share similar characteristics, within which a sample is drawn (Ghauri \& Grønhaug, 2005). The entire population of this research consists of all small to medium cafés in South Africa. However, due to budget and time constraints, a sample of five to six cafés in the Braamfontein area was used for this research. As part of the data collection technique, the non-probability sampling was used as it is deemed as the most ideal for a qualitative study. Convenience sampling was chosen because of its benefits. Convenience sampling is inexpensive, efficient and generally the respondents are easily accessible and willing to participate in the study. Convenience sampling technique is useful for a qualitative study because it generates comprehension, ideas and concepts (Malhotra \& Peterson, 2006). With a goal of interviewing 6 café owners or managers, only 5 were available to participate in the study. Braamfontein was chosen as the study area because it is a newly developed area that has been undergoing gentrification since 2004.

Data collection: As part of the procedures that were used in gathering data for the study, the researcher approached each of the café owners/ manager/marketer or respondents and scheduled interviews with them. Then afterwards, the researcher met up with the respondents on the confirmed dates to have a one on one in-depth interview with them. Each interview was recorded. The interview recordings were transcribed followed by extraction of themes and data was analysed through a case study analysis. Through this method, the researcher created a case study which involved an intensive examination of selected cases of the phenomenon of interest (Malhotra \& Peterson, 2006).

Questionnaire design: The designed questionnaire consisted of a cover letter inviting respondents to participate in the study. In addition, the study stated that it is completely voluntary. The aim of the questionnaire was to establish two things. First, to determine whether or not small to medium cafés implement an integrated marketing strategy that embraces both the marketing mix and online marketing. Secondly, to identify whether there is an alignment between their marketing strategies and organisational objectives.

Reliability and Validity: Reliability is a test used to check whether a scale yields the same results when used more than once. Also, reliability is achieved when a scale has no random error. Various methods are used to check for reliability and they include test-retest, internal consistency method and alternative forms (Malhotra \& Peterson, 2006). Content validity, criterion validity and construct validity are the main techniques used to measure validity. For this study, content validity was used as it is less complex and helps with data analysis. Content validity measures the extent to which content of a scale represents what the scale aims to measure. The researcher and his supervisors checked the questions to determine if they measure what research aims to achieve. A pre-test of the research tool was conducted before administrating it to respondents.

\section{Data Analysis and Results}

The findings from the data are explained under following themes.

The café's adoption and implementation of an integrated marketing strategy that embraces both the marketing mix and online marketing: It was deduced from the interviews conducted with café owners or brand strategists that they certainly do implement an integrated marketing strategy that embraces both the marketing mix and online marketing. In terms of marketing mix, there is a common thread that runs through their marketing strategies. Three of the four p's of the marketing mix proved to be the most important, while promotion was rated as the least important. The café owners/managers/marketers engage with online 
marketing for communication purposes through a variety of platforms which include their website, social media and so on. The findings from the marketing mix are as follows:

Product: All the cafés possess a product with a unique selling proposition that is aligned with the needs of their consumers. Their respective competitive advantages are rooted in their coffee offerings of different types from different regions, in different food pairings, and menus that set them apart from each other. Love Food and Coffee, value proposition in the café owner's words is:

"Great, healthy, fresh, tasty, wholesome food".

The owner prides herself in the fact that her food and coffee offering is healthy (i.e. it does not contain any colour ants or artificial substances), is locally sourced and wholesome, meaning it has her touch of years of culinary expertise compared to the mass produced food from multinational cooperation's. Most of the respondents emphasised the importance of updating the menu on a regular basis with new exciting tantalising food pairings, to keep loyal consumers interested in their brands, one respondent said:

"To keep our customers happy with a diverse food and coffee offering, we update our menu on a regular basis to keep them interested in our cafés."

In addition, various extrinsic cues such as packaging are used to identify the product and the brand and to reinforce a certain brand image in the minds of the consumers.

Price: With regards to their pricing strategy, cost is the primary factor considered in determining the price points. In fact, for most of the respondents, cost is the only factor taken into account when setting prices. What is astonishing about this is that these cafés operate in a concentrated and saturated location, were competition is intense, yet they don't consider each other's prices. One respondent said:

“We only consider cost went setting prices, i.e. we don't consider customers' perception or preferences of the food and competitors' prices because our low price model works for us". Fixed pricing and promotional prices are two of the most commonly used pricing strategies. Promotional pricing which entails offering discounts, free food tastings and coffee for a limited period to loyal customers is used frequently as part of the café's customer relationship management programme. One of the cafés, Double-shot café uses loyalty cards to encourage consumers to return to their establishment.

Place: Place also proved to be a significant part of the marketing mix, primarily because it is means, by which a product is made available to consumers. The physical premise is a platform used to make a product accessible to consumers (Yeu et al., 2012). All the cafés have a creative, clean and distinct interior and exterior design aesthetic that helps to communicate the DNA of the brand. Also, the cafés have an open plan spacious design that helps facilitate social gatherings and interactions between the owners, staff and consumers. This is done with the intention of establishing long term mutual beneficial relationships with customers. When asked about how is their place different from other cafés, one of the respondents said:

"The exterior is very colourful and vibrant. Also, most part of it is made up of glasses, so customers can see the outside while enjoying a cup of coffee. The interior is an open spacious area, and that allows us to interact with the consumers and build relationships with them".

The respondents expressed their desire to get know their customers on a personal basis. This highlights that café owners and brand strategists apprehend the significance of building a loyal customer base and as retaining loyal customers is far more cost effective than recruiting new ones (Ozgener \& Iraz, 2006).

Promotion: As mentioned promotion proved to be the least important element of the marketing mix. Cafés have no to limited promotional strategies. One of the participants said:

"We don't use promotion strategies".

That can be attributed first, to respondents expressed lack of interest in investing in promotional activities. From what the researcher has deduced, some see promotion as unnecessary as the other three elements are playing an instrumental role in keeping the business going and growing. This attests to the notion that SMME's can do without promotion (Tsikirayi, Muchenje \& Katsidzira, 2013). Secondly, from the interviews it was evident that they don't have ideas on cost effective and creative promotional platforms to promote their businesses. However, event marketing proved to be a popular mechanism of promoting the cafés. Doubleshot coffee and tea hosts' regular events where the owners educate their consumers on coffee beans and on the art of making a pleasant cup of coffee. Also, Love food café hosts diners club regularly to give consumers 
an exquisite dining experience. These attempts are aimed at putting the respective brands out there. On the other hand, all the respondents expressed interest in using alternative and inexpensive methods to promote their brands.

The use of On-line marketing: The data collection proved that cafés do use online marketing to achieve marketing objectives which include, introducing and persuading, reminding target audience. The main business website, various social media platforms like twitter, Facebook and Instagram are used as means of achieving certain marketing objectives. On the other hand, the recently popular Instagram is primarily used to give consumers a vivid picture of a message.

The alignment between cafés marketing strategies with their organisational vision, goals, marketing and financial objectives: The results obtained have confirmed that the café owners and brand strategists do align their marketing strategies with their organisational vision, goals and objectives. One of the respondents when asked about both the vision of your business and the short term goals of your business, she replied: "To give people a healthy, fresh lunch alternative to the mass produced fast food." and to "Continue producing fresh tasty wholesome food with great service." The product unique selling proposition is, "Great, healthy, fresh, tasty, wholesome food". This signals that she remains true to the businesses vision and addresses its short term goals through offering a product that is hale and hearty, appealing and delicious. The businesses main core advantage is that it offers "home-made" food with the touch of her cooking skills that her customers like, as opposed to the standardised unhealthy offering from most food outlets. However, the researcher has inferred from the results obtained that there are no formal structures put in place to ensure that their marketing strategies are aligned with their organisation goals and objectives. In addition, there are no reliable and proper systems put in place to see whether a marketing strategy has enabled them to achieve their set goals and objectives. For instance, after launching a website, a marketing campaign or posting a tweet on a certain content like an upcoming event, the café owners don't use any 'results orientated' technique, like Google analytics to monitor the results. Google analytics is an effective tool that enables a business owner to measure traffic to their website, assists them get a picture of how visitors engages with their pages, their consumers psyche, purchasing behaviour and patterns for maximum impact. Google analytics are reliable, inexpensive, user friendly, and easily accessible to SMME café owners, and thus should be used to measure results and identify areas of improvements (Google, 2014).

The locations impact in enhancing the development and growth of small to medium cafés within the Braamfontein area: Factors that lead to the long term sustainable success of service based organisations include, store image, service level, and location. "Of these, store location is perhaps the most important determinant of success" (Ghosh \& Craig, 1983, p 56). Same can be said about the impact of Braamfontein in the success of the sampled cafés and the results obtained from the research are a testament to that. When asked about what made the respondent set up his business in Braamfontein, one respondent said: "Since regeneration, the area has attracted like-minded middle class people, who are yearning to be part of the coffee culture." The respondent expressed how they are able to satisfy the community's need to be part of the coffee culture phenomenon through offering superior quality coffee from different regions globally. The area was chosen because it is a newly developed area that has been undergoing gentrification since 2004 . Braamfontein Improvement District project was launched to readdress the urban decay that led to the degeneration of the city (Braamfontein, 2014). The project has proved to be a success as Braamfontein is now a cosmopolitan district with corporate offices, cafés, restaurants, bars, clothing stores, art galleries and so on (Braamfontein, 2014). Over the past ten years, the area has become a vibrant business hub that attracts likeminded people of all ages on a daily basis. It was clear from the respondents' answers that the choice of location has been a major contributor to their businesses success. The owner of Double shot tea and coffee explained how the café was design to allow the consumers to enjoy the newly revamped Braamfontein.

Proposed effective integrated marketing strategy that embraces both, the marketing mix and online marketing techniques, in order to aid cafés, achieve their pre-specified organisational objectives: The proposed marketing strategy is based on Rendón, Martínez, \& Flores (2014), a study on marketing strategies for hotel industry internationalization in Morelia and the researchers' empirical and theoretical findings. 
The use of the marketing mix: Product - the product is considered as a pillar of a marketing strategy, meaning without a functional need satisfying and in demand product, a marketing strategy cannot realise set organisational objectives (Fransiska et al., 2012). The definition of product varies within literature; however, a common thread of "need satisfying" runs through different definitions. Strauss, Frost \& Ansary (2009) defines product as a "bundle of benefits". When designing a product, cafés needs to consider 3 points which is a) who is the product aimed at? b) What value can consumers get c) how to position the product in the market.

- To start with, products should address the needs of a market that is underserved, meaning there is a demand for products that is not being adequately met (Hutchison, Macy \& Allen, 2010). Therefore, ideally, new café owners need to come up with a new coffee offering and menu that is in high demand by a specific market. Recently there has been a prosperous and upward trend of cafés around South Africa, especially in cosmopolitan cities like Johannesburg (Bizcommunity, 2013). In other words, there is a need for cafés as the local coffee culture continues to grow, however to break through the clutter and stand out among the rest, new cafés need to find a niche market or create a need or demand for a specific type of coffee or food pairings.

- Secondly, potential and current café owners need to consider the benefits that can be derived from their product by consumers. While purchasing, a good consumer seeks products that offer high value proposition through weighing the benefits against the cost of acquiring that product. Café owners can provide value to coffee lovers through providing them with superior quality coffee, supplementary services (like free Wi-Fi), a great place to enjoy the food and coffee and promotional rewards at a reasonable cost.

- Thirdly, the café owners need to position their product differently from others. Differentiation can be achieved through using different types of coffee beans like organic beans from other untapped areas or through different brewing methods like theatrical brewing methods or alternative methods. Also, product differentiation can be attained through an in house barrister coffee expertise. Packaging is also key, as it can be used as a tool to set a café apart from others and to communicate a DNA of the brand (Young \& Pagoso, 2008). Packaging offers protection and facilitates the transportation, storage of a product. One of the sampled café-Velo, differentiated itself through offering art pieces as part of its product offering. The art feature is aligned with the organisations brand DNA and vision, which is created to a space for both the art and coffee lovers to come together and enjoy a cup of coffee or a scrumptious meal and art pieces. The majority of the respondents highlighted the importance of updating menu regularly to keep consumers interested in their respective cafés. They expressed the need to, because regular customers easily get bored with the same product offering. One of the world's largest fast food chains McDonald also update its menu frequently to keep up with their customer's ever changing tastes (Yeu et al., 2012). Therefore, aspiring cafés need to update their menu regularly according to the rapid changing needs of consumers without compromising the standard of their products, vision, goals and objectives.

Place: a platform in which a consumer can get access to a desired product or service. This facet of the marketing mix pertains to the process of making the product accessible to the consumer when they need it most. The various methods of delivery are referred to as channels of distribution (Hutchison et al., 2010). The most used and preferred channel is the physical premise. However, one of the respondents uses e-commerce to avail their products which include design pieces to its consumers. Therefore, potential café owners need to consider using the internet as platform to sell their products. Distribution systems traditionally consist of channel intermediaries such as wholesalers and retailers (Hutchison et al., 2010). Most of the sampled cafés are both the wholesalers and the retailers, in the sense that they select their preferred beans and ingredients, apply their expertise through respective brewing methods and sell through their cafés. This approach is ideal because the cafés have complete control of the entire supply chain and that can maximise the efficiency of the distribution channel.

The image of the place is an important factor to consider, as it has the potential to shape consumer's perception about the brand, and consequently brand equity (Dodds, Monroe \& Grewal, 1991). A place can be used as a medium to communicate a desired message about the brand to the consumers. Therefore, cafés need to create a unique design aesthetic that is aligned with the vision of the brand to separate themselves from competitors. Studies have shown that consumers associate places with a good image with high quality 
products (Dodds et al., 1991). Therefore, premium café who offer superior quality coffee needs to reflect that through the interior and exterior design of the café. In essence, marketers need to be cognisant of the fact that an appealing store or cafés draws consumers in and increases consumer's satisfaction levels. In addition, majority of the respondent highlighted the importance of a spacious open design café that facilitates interactions and relationships between café owners, workers and customers. It is important to form long term mutual beneficial relationships with loyal customers, as they contribute significantly to the revenue base (Ozgener \& Iraz, 2006). Therefore, it would be wise for aspiring café owners to follow suite with the spacious clean and open interior design.

Pricing: In the marketing mix, pricing is of paramount importance because it is the only mechanism used to generate a profit (Sen, 2013). The three commonly used pricing strategies in the café industry are the 'costbased pricing', 'fixed pricing' and 'promotional pricing'. All three pricing strategy are recommended because of their ability to enable the already established cafés to reach their financial objectives. First, the cost based pricing is highly effective because it factors the total cost of producing, promoting and distributing the product and then adds an additional amount to meet the businesses profit target (Hutchison et al., 2010). The only downside with this strategy is that it doesn't consider consumer's perspective and other competitors pricing strategies (Hutchison et al., 2010). However, data proves that the SMME cafés can do without considering competitors pricing strategies, provided that they offer differentiated products. Secondly, the promotional pricing is highly recommended because it enables businesses to introduce various products to consumers as its nature encourages consumers to try out a proposed product. Implementing a reward programme and offering discounts to regular customer helps build long term sustainable mutual beneficial relationships between the customers and the café.

Another promotional tactic that can be used by café owners is putting a sales mark on a product; this method is highly effective because it drives the demand of a product up (Inman et al., 1990). Also, the demand of a product tends to increase when changing the price of a complementary product (Nunes \& Boatwright, 2004). Therefore, cafés owners can decrease the price of a cup cake or any product that complements coffee to increase the demand of the coffee when in low demand. Another approach that can be taken to increase the demand of a product or to introduce it to consumers is to offer it at no cost. Offering a free product has its benefits, which are; it reduces cognitive dissonance in consumers, encourages product adoption, repeats purchases and increases the demand of a complementary product (Ahmetoglu, Furnham \& Fagan, 2014). Therefore, to increase the demand of a new coffee bean in the café, an owner can offer a complementary product for free as an incentive to encourage the consumers to try out the new coffee offering. Third, fixed pricing entails charging all consumers the same price for all goods and services. All sampled cafés use this strategy as it is deemed fair by them and consumers. Charging different prices for a cup of cappuccino latte to different consumers will be deemed as price discrimination which will subsequently turn away customers. Therefore, fixed pricing is the appropriate strategy within the café industry due to the nature of the product offering.

Promotion: is a paid tool that enables SMME's to communicate basic information about the products unique selling proposition, its benefits, price points and any other relevant information to the market (Kotler, 2006). As mentioned above, promotion proved to be the least important aspect of the marketing mix. Data collected is in favour of Tsikirayi et al. (2013) perspective, that not all promotional activities yield desired outcome and that SMME's can do without promotion. Depending on the vision, goals and the objectives of the business, a new café can choose not to invest heavily in promotional activities. However, to be successful in the early stages of the business without promotion, café owners will have to leverage on the other three p's to communicate a compelling and distinct message about their business that will set them apart from competitors and bring consumers in. In addition, having a cult following can enable the business to grow and flourish. Members of a cult tend to have a strong sense of community and loyalty towards the brand and will often support and promote it to others through positive word of mouth (Lindberg-Repo \& Grönroos, 1999).

For instance, Zara a global fashion brand has managed to succeed and continues to remain on a positive trajectory with no to minimal advertising and promotion. The success of the brand can be attributed to its fast paced-fashion business model, which has a short production cycle compared to its competitors (Ferdows, Lewis \& Machuca, 2003). In other words, Zara has acquired an incomparable competitive advantage of churning out new trendy clothes at reasonable prices on a regular basis. Zara's success is a testament to the 
notion that small, medium even large businesses can succeed with less or no promotion and cafés are advised to take this approach provided that they leverage effectively on other three p's of marketing mix or they create an inimitable competitive advantage that will help form a loyal and large customer base. However, the researcher recognises the imperative role that can be played by promotional activities in enabling a business to achieve its vision, goals and organisational objectives. Promotion is a potent tool that can help a business realise high profit and market share (Fransiska et al., 2012). Therefore, café owners that see promotion as a must can either employ an 'attraction' or a 'push' strategy. Attraction strategy entails employing a promotional mix with an intention of capturing the consumer's attention and subsequently encouraging them to purchase product offering. A push strategy is a rigorous tactic that is aimed at increasing products sales volume (Rendón et al., 2014).

The use of online marketing: The emergence and progression of technology has led the inception and success of online marketing. As a result, most firms have adopted online marketing as means of communicating a desired message to their target market (Kiang, Raghu \& Shang, 2000). The same can be said for small to medium businesses within the café industry. The research proposes a blend of the corporate website, social media, direct emailing and search engines as an online marketing strategy. In addition, google analytics are recommended as formal reliable method of tracking the progress of online marketing activities. Corporate website - Café owners can use a corporate website as a platform to communicate basic but imperative information about cafés (for instance the address, opening times, menu, product offering, prices and so on). To create an effective website, café owners need to employ a combined approach that takes into account information system and marketing factors (Salavati \& Hashim, 2015). Information system factors pertain to design functionality, accessibility quality of content, and navigability, in other words, the website must contain relevant information be clean, clear and easy to manoeuvre in a short period. Marketing factors refer to the use of the website to promote products, sell online, and confirm orders and so on (Chiou, Lin \& Perng, 2011).

After thematic analysis of research data, a conceptual framework was developed. Below is an illustration of the research conceptual framework.

Figure 1: Research Conceptual Framework

Integrated Marketing Strategy

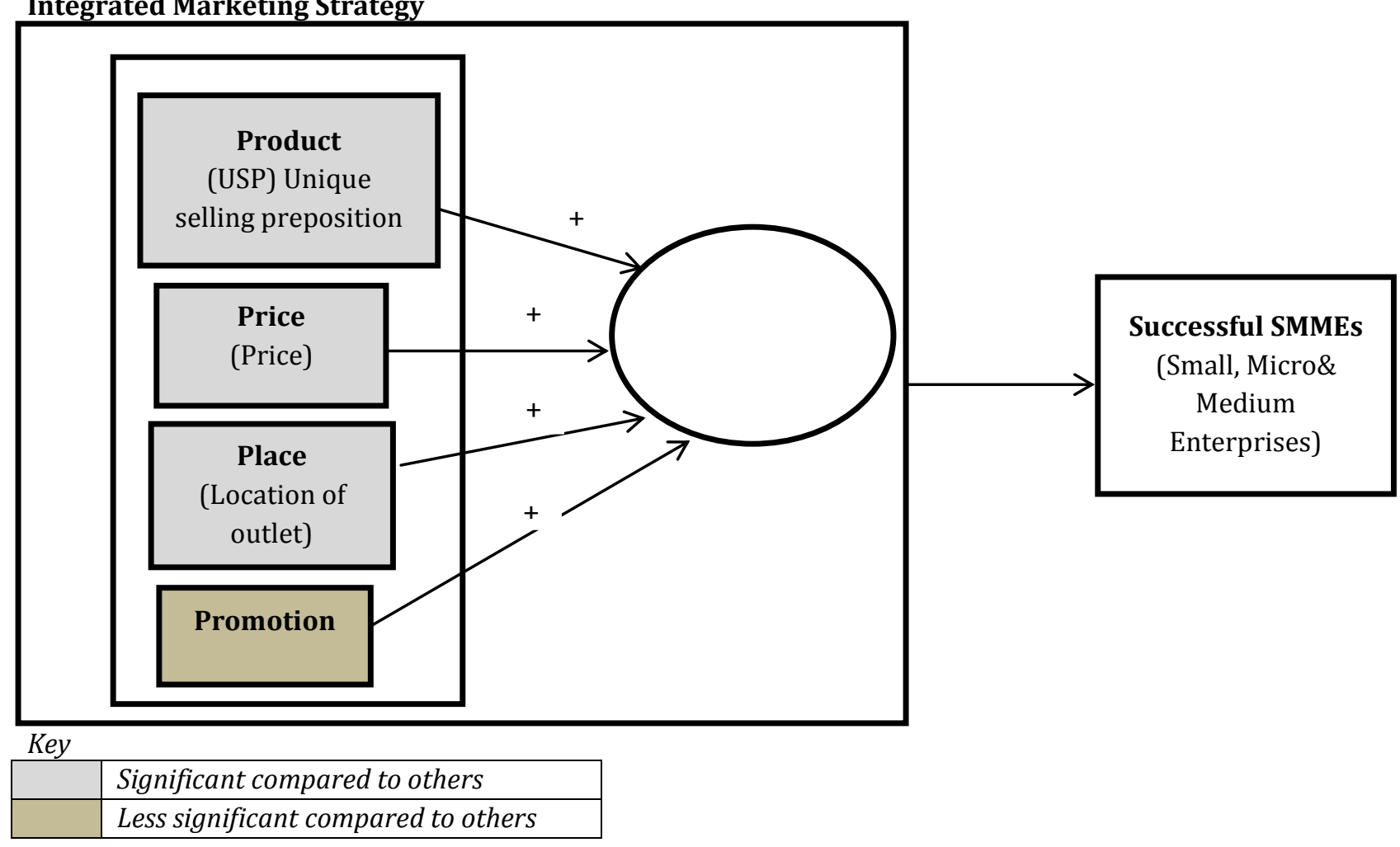


Above is an illustration of the research conceptual framework of the present study. After analysis of themes observed in the study, it was found that the marketing mix (price, product, place and promotion) influences cafés online marketing strategy, together making effective integrated marketing strategies to bring about success to SMME cafés.

Marketing Implications: This concluding section deliberates on the results of the study; entrepreneurial implications within the South African context as well as the conclusions of the study. The researcher has inferred from the data obtained, observation, theoretical and empirical findings that small to medium cafés have an informal and flexible approach to marketing in comparison to big corporate who have formal and expensive structures and division set up to achieve pre-specified marketing objectives. Therefore, marketers and potential café owners need to be cognisant of that. Also, marketers need to recognize the importance of embracing and employing an integrated marketing strategy. They need to understand how elements of the strategy interact and their overall impact on the effectiveness of the strategy. Moreover, to be effective, the integrated marketing strategy needs to be informed by the organisations vision, goals and objectives. Based on the findings of the study it is observed that as far as the marketing mix is concerned, product is a key element for all cafés as it is viewed by most customers to be consistent with satisfaction of their needs. This therefore implies that marketers should ensure that if they are to gain new customers and retain existing customers the product (coffee) should always be present and in the desired quantities that the customers want. It is further observed in the present study that price is also a key element as far as the marketing mix is concerned. However, café owners did not consider the prices charged by competitors to be a matter of concern implying that as much as it played a role in their business, it did not have an overall influence in their decision making process. For example, lowering or increasing their prices based on competitor behaviour. As for place, this had a significant role as part a cafés business strategy, as this was considered to have much influence on shaping perceptions that consumers have of a destination. This view is supported by Assaker (2014) who considered a place as being associated with perceptions, expectations and emotional thoughts that an individual might have of that particular place. The final element of the marketing mix, promotion is considered to be the least important by both café owners and customers. This implies that possibly coffee drinkers do not see much value in the actual product being promoted, but possibly they purchase the product because there are already informed about it. Promotions would not persuade their minds which are different from the other elements such as place and product, which are considered by café owners and customers to be of significant importance.

Theoretical Contribution of the Study: Based on observations from the study four variables were observed and these were: product, place, price and promotion, as a part of marketing mix. These variables had an influence on the online marketing strategy of a café. The key theoretical contribution was the observation of integrated marketing strategy comprising of marketing mix and online marketing's usefulness to the success of SMMEs.

\section{Conclusion}

The research has proven that café owners or brand strategists certainly do implement an integrated marketing strategy that embraces both the marketing mix and online marketing. The three p's (product, place and price) of the marketing mix proved to be the most significant for a café, while promotion proved to be the least significant. To elaborate, a product with a unique selling proposition, an effective pricing strategy and revenue mechanisms, well designed place with limited to no promotion can lead to the success of a small business, depending on an industry. Online marketing, also proved be an effective platform to help communicate a desired message to the target audience. Location is also an imperative determinant of whether a business is going to be successful or not. The gentrification of Braamfontein area has transformed the district into a business and cosmopolitan place that attracts young and old middle class coffee lovers, and thus led to the success of the cafés. Furthermore, the research confirmed that there is an alignment between the cafés marketing strategy and their organisational vision, goals and objectives. In other words, café owners or brand strategists consult with their vision, goals and objectives before deciding on introducing a new product or menu, changing the design of their café, hosting an event or posting an update on social media platforms. 


\section{References}

Agupusi, P. (2007). Small business development and poverty alleviation in Alexandra, South Africa. In second meeting of the Society for the Study of Economic Inequality, East Anglia, Norwich, UK, ECINEQ Society, Berlin,(P. Agupusi@ uea. ac. uk) Altenburg, T, and Drachenfels, CV (2008) Creating an enabling environment for private sector development in Sub-Saharan Africa, Universität zu Köln, Luxembourger Str (Vol. 32550939).

Ahmetoglu, G., Furnham, A. \& Fagan, P. (2014). Pricing practices: A critical review of their effects on consumer perceptions and behaviour. Journal of Retailing and Consumer Services, 21(5), 696-707.

Assaker, G. (2014). Examining a hierarchical model of Australia's destination image. Journal of Vacation Marketing, 20(3), 195-210.

Bizcommunity. (2013). Coffee culture grows in South Africa. Retrieved 09 24, 2014, from http://www.bizcommunity.com/Article/196/168/88213.html

Borden, N. (1964). The concept of marketing mix. Journal of Advertising Research, 2(1).

Braamfontein. (2014). Braamfontein Management District. Retrieved August 05, 2014, from http://www.braamfontein.org.za

Cagliano, R., Caniato, F. \& Spina, G. (2003). E-business strategy: how companies are shaping their supply chain through the internet. International Journal of Operations \& Production Management, 23(10), 11421162.

Caprino, K. (2013). The 7 Worst Marketing Blunders Small Businesses Make. Retrieved 03 26, 2014, from Forbes.com: http://www.forbes.com/sites/kathycaprino/2013/01/24/the-7-worst-marketingblunders-small-businesses-make/

Chiou, W. C., Lin, C. C. \& Perng, C. (2011). A strategic website evaluation of online travel agencies. Journal of Tourism Management, 32(6), 1463-1473.

Consumer Foodservice. (2005). Consumer Foodservice in South Africa. South Africa: Euro monitors International.

Czinkota, M. \& Ronkainen, I. (2012). International marketing. Cengage Learning.

De Waal, J. J. \& Pienaar, J. (2013). Towards understanding causality between work engagement and psychological capital. SA Journal of Industrial Psychology, 39(2), 1-10.

Dodds, W. B., Monroe, K. B. \& Grewal, D. (1991). Effects of price, brand, and store information on buyers' product evaluations. Journal of marketing research, 2, 307-319.

Edwards, L. \& Schoer, V. (2001, May). The structure and competitiveness of South African trade. In TIPS Annual Forum, September (pp. 10-12).

Erdoğmuș, İ. E. \& Cicek, M. (2012). The impact of social media marketing on brand loyalty. Procedia-Social and Behavioral Sciences, 58, 1353-1360.

Ferdows, K., Lewis, M. \& Machuca, J. A. (2003). Zara. In Supply Chain Forum. An International Journal, 4 (2), 62-67. Taylor \& Francis.

Fransiska, Y., Andhika, F., Indra, M. \& Rengganis, R. (2012). Determining the Most Effective Promotion Strategy for Clothing Company in Bandung, Indonesia. Procedia Economics and Finance, 4, 120-129.

Ghauri, P. N. \& Grønhaug, K. (2005). Research methods in business studies: A practical guide. Pearson Education.

Ghosh, A. \& Craig, C. S. (1983). Formulating retail location strategy in a changing environment. The Journal of Marketing, 3, 56-68.

Google Analytics. (2014). Google Analytics. Retrieved October 13, 2014, from http://www.google.co.za/analytics/why/

Greenley, G. E. (1984). An understanding of marketing strategy. European Journal of marketing, 18(6/7), 90103.

Gurau, C. (2008). Integrated online marketing communication: implementation and management. Journal of communication management, 12(2), 169-184.

Hutchison, T. W., Macy, A. \& Allen, P. (2010). Record label marketing. Taylor \& Francis.

Inman, J. J., McAlister, J. \& Hoyer, W. D. (1990). Promotional signal: proxy of a price cut. Consumer Res, 17(1), 74-81.

Jain, C. S. (2000). Marketing Planning and Strategy (Sixth Ed.). Connecticut: School of Business Administration. University of Connecticut. 
Kiang, M. Y., Raghu, T. S. \& Shang, K. H. M. (2000). Marketing on the Internet-who can benefit from an online marketing approach? Decision Support Systems, 27(4), 383-393.

Kotler, P. (2006). Integrated Advertising, Promotion, and Marketing Communications. Prentice Hall.

Lamb, C. W., Hair, J. F., Mcdaniel, C., Boshoff, C., Terblanche, N. S., Elliot, R. \& Klopper, H. B. (2010). Marketing. 4th South African edition. Cape Town: Oxford.

Lee, C. H., Ko, E., Tikkanen, H., Phan, M. C. T., Aiello, G., Donvito, R. \& Raithel, S. (2014). Marketing mix and customer equity of SPA brands: Cross-cultural perspectives. Journal of Business Research, 67(10), $2155-2163$.

Levinson, J. C. (2007). Guerrilla Marketing: Easy and Inexpensive Strategies for Making Big Profits from Your Small Business. Houghton Mifflin Harcourt.

Lindberg-Repo, K. \& Grönroos, C. (1999). Word-of-mouth referrals in the domain of relationship marketing. Australasian Marketing Journal (AMJ), 7(1), 109-117.

Llorens, S. (2014). Start-Ups and the Internet: The case of Strutz'Sole Angel®. Journal of Business Cases and Applications, 11(1).

Louw, L. \& Venter, P. (2012). Strategic management: Developing Sustainability in Southern Africa. Cape Town: Oxford University Press. Southern Africa.2nd ed.

Malhotra, N. K. \& Peterson, M. (2006). Basic Marketing Research: a Decision-Making Approach (second edition ed). New Jersey: Pearson Prentice Hall. Smith.

Murphy, M. (2001). Top-ten small-business mistakes. Metal Finishing, 99(7), 2.

National Small Business Act. (1996). South African Government. Pretoria. Retrieved 11 01, 2016 fromhttps://www.thedti.gov.za/sme_development/docs/act.pdf

Nunes, J. C. \& Boatwright, P. (2004). Incidental prices and their effect on willingness to pay. Journal of Marketing Research, 41(4), 457-466.

Olawale, F. \& Garwe, D. (2010). Obstacles to the growth of new SMEs in South Africa: A principal component analysis approach. African journal of Business management, 4(5), 729.

Özgener, S.. \& İraz, R. (2006). Customer relationship management in small-medium enterprises: The case of Turkish tourism industry. Tourism Management, 27(6), 1356-1363.

Rendón, O. H. P., Martínez, R. M. \& Flores, M. S. R. (2014). Marketing Strategies for Hotel Industry Internationalization in Morelia. Procedia-Social and Behavioral Sciences, 148, 271-279.

Salavati, S. \& Hashim, N. H. (2015). Website adoption and performance by Iranian hotels. Tourism Management, 46, 367-374.

Şen, A. (2013). A comparison of fixed and dynamic pricing policies in revenue management. Omega, 41(3), 586-597.

Small Enterprise Development Agency. (2013). Research study to identify needs opportunities and challenges of SME's in the plastic and chemical sector. Pretoria, South Africa: Underhill Corporate Solutions (UCS).

Strauss, J., Frost, R. \& Ansary, A. I. (2009). E-marketing. Pearson Prentice Hall.

Tsikirayi, C. M. R., Muchenje, B. \& Katsidzira, Z. (2013). Impact of integrated marketing communications mix (IMCM) in small to medium enterprises (SMEs) in Zimbabwe as a marketing tool. Research in Business and Economics Journal, 7(1).

Varadarajan, R. (2010). Strategic marketing and marketing strategy: domain, definition, fundamental issues and foundational premises. Journal of the Academy of Marketing Science, 38(2), 119-140.

Williams, A. (2006). Tourism and hospitality marketing: fantasy, feeling and fun. International Journal of Contemporary Hospitality Management, 18(6), 482-495.

Yeu, C. S., Leong, K. C., Tong, L. C., Hang, S., Tang, Y., Bashawir, A. \& Subhan, M. (2012). A Comparative Study on International Marketing Mix in China and India: The Case of McDonald's. Procedia-Social and Behavioral Sciences, 65, 1054-1059.

Yoo, B., Donthu, N. \& Lee, S. (2000). An examination of selected marketing mix elements and brand equity. Journal of the academy of marketing science, 28(2), 195-211.

Young, F. C. \& Pagoso, C. M. (2008). Principles of Marketing. Sampaloc: REX Book Store, 7. 